\title{
EFFECT OF DRYING TEMPERATURE AND METHOD OF EXTRACT PREPARATION ON ANTIOXIDANT ACTIVITY OF EDIBLE FLOWERS OF SOME ORNAMENTAL PLANT SPECIES
}

\author{
Department of Horticulture, West Pomeranian University of Technology in Szczecin, Poland
}

\begin{abstract}
Edible flowers are a popular food ingredient in many regional cuisines, especially Asian and Middle Eastern ones. Drying is one of the most popular methods of preserving flowers. On the other hand, a common method of consuming dried edible flowers is to use them for preparing various kinds of beverages, both alcoholic and non-alcoholic ones. The paper presents the results of the laboratory analyses concerning the content of biologically active compounds in dried flowers in three temperature variants $\left(\sim 25^{\circ} \mathrm{C}, 35^{\circ} \mathrm{C}\right.$ and $\left.70^{\circ} \mathrm{C}\right)$, which were used to select the material constituting the basis for obtaining various types of water (infusions, decoctions, macerates) and alcohol extracts (with the use of $50 \%, 80 \%$ and $96 \%$ ethanol and repeated extractiong method using $96 \% \mathrm{EtOH}$ ), and then their antioxidant activity evaluation. The research material consisted of ornamental plant species with flowers of high biological value: Mimulus $\times$ hybridus L. ('Magic Yellow' and 'Magic Red'), Hemerocallis $\times$ hybrida Hort., Monarda didyma L., Paeonia lactiflora Pall. ('Sarah Bernardt', 'Dr. Alexander Fleming' and 'Karl Rosenfield'). The experiment was carried out in the years 2014-2015 in the Department of Horticulture of the West Pomeranian University of Technology in Szczecin. On the base of the chemical analyses results the most favourable drying temperature variant was selected for each tested flower cultivar. For flowers $M$. × hybridus L., M. didyma L. and $H$. $\times$ hybrida Hort. it was $35^{\circ} \mathrm{C}$; dried flowers were characterised by the highest content of biologically active compounds and the highest antioxidant activity. In the case of three cultivars of $P$. lactiflora Pall. the most favourable drying temperature was $\sim 25^{\circ} \mathrm{C}$. Among the water and alcohol extracts of the studied edible flower species, the decoction indicated a higher content of antioxidant compounds. The highest values of antioxidant activity were observed in extracts prepared on the basis of peony flowers.
\end{abstract}

Key words: Mimulus, Monarda, Hemerocallis, Paeonia, vitamin C, carotenoids, polyphenols, DPPH, ABTS, FRAP.

\section{INTRODUCTION}

Today, food is becoming increasingly diverse, striving to combine new ingredients with some potential health benefits which can improve consumer health (Leonti 2012; Pires et al. 2017; Zheng et al. 2019). This search for new food products is also a pursuit of the visual and taste attractiveness of dishes that can be achieved by using edible flowers (Grzeszczuk et al. 2016; Matyjaszczyk and Śmiechowska 2019; Rezende et al. 2019). Some restaurant chefs around the world use them in their dishes (Kelley et al. 2001; Łuczaj et al. 2012; Pires et al. 2017). Still, edible flowers are an unexplored niche market while they have been

Corresponding author: Monika Grzeszczuk, Department of Horticulture, West Pomeranian University of Technology in Szczecin, Juliusza Słowackiego 17, 71-434 Szczecin, Poland, e-mail: monika.grzeszczuk@zut.edu.pl, ORCID: 0000-0003-1347-6764. 
applied in many traditional dishes, sauces, oils, salads or desserts since ancient times (Mlcek and Rop 2011; Xiong et al. 2014; Koike et al. 2015; Petrova et al. 2016). In the herbal tradition, fresh and dried herbaceous plants, including their flowers, have been used in phytotherapy for centuries (Adamczak et al. 2015; Śmiechowska 2018). Drying is the oldest and the most popular method of preserving edible flowers. The raw material obtained in this way is commonly used to make water and alcoholic extracts. In European countries, the most common use of flowers in human nutrition is the preparation of hot drinks or alcohols (Chen et al. 2018; Hussain et al. 2019). We drink tea (infusions), decoctions or tinctures also for their therapeutic properties and for our own well-being (Toda 2011; Navarro-González et al. 2015; Ngoitaku et al. 2016).

Over eighty different species of plants with edible flowers can be safely used as food (Stefaniak and Grzeszczuk 2015). We harvest them from ornamental plants as well as herbs, vegetables, shrubs and fruit trees. In addition to their decorative and taste qualities, edible flowers have valuable nutritional and health-enhancing properties (Mlcek and Rop 2011; Lara-Cortés et al. 2014; Grzeszczuk et al. 2016; Zheng et al. 2019). In general, the edible flowers have a similar chemical composition to other parts of plants. However, they are distinguished by their high moisture, low fat and protein content, which makes them a low-caloric raw material (Mlcek and Rop 2011; Rop et al. 2012; Lara-Cortés et al. 2013; Navarro-González et al. 2015). Moreover, they present a wide range of high antioxidant molecules, such as phenolic compounds, carotenoids, vitamins (Nurul and Asmah 2012; Loizzo et al. 2016; Pires et al. 2017). Among other things, it is the colour of flowers that depends mainly on the content of carotenoids and anthocyanins (Friedman et al. 2010; Benvenuti et al. 2016; Matyjaszczyk and Śmiechowska 2019). Natural antioxidants are present in all parts of plants, but flowers have the highest concentrations of these compounds (Kaisoon et al. 2012; González-Barrio et al. 2018). Moreover, they contain many mineral compounds, essential oils and polyphenols - compounds with very high antioxidant activity (Rop et al. 2012; Xiong et al. 2014; Navarro-González et al. 2015; Petrova et al. 2016). The antioxidant activity of flowers is precisely related to their phenolic compounds, which show mechanisms of action that take place in intercepting or blocking chain reactions caused by free radicals. This is the way to avoid the ageing of cells and the emergence of chronic diseases (Araújo et al. 2013; Rezende et al. 2019). Knowledge of the harmfulness of free radicals encourages the search for substances supporting the natural antioxidant defence of the body. The research on secondary metabolites derived from plants with recognized dietary or therapeutic effects is of particular interest (Cybul and Nowak 2008). Consuming food rich in natural antioxidants helps to prevent coronary heart disease, diabetes, cancer and degenerative diseases such as Alzheimer's disease (Toda 2011; Gonzalez-Barrio et al. 2018; Zheng et al. 2019).

Most studies on edible flowers have been focused mainly on the sensory characteristics of flowers and the comparison of their therapeutic values with other parts of the plant. Admittedly, there are some scientific publications on edible flowers, but few studies concerning their conservation, i.e. the selection of appropriate drying temperature and comparison of their potential to be used in various forms of extracts. 
The aim of this study is to assess the content of biologically active compounds and antioxidant activity of flower extracts of selected plant species (Mimulus $\times$ hybridus L. 'Magic Yellow' and 'Magic Red', Hemerocallis $\times$ hybrida Hort., Monarda didyma L., Paeonia lactiflora Pall. 'Sarah Bernardt', 'Dr Aleksander Fleming' and 'Karl Rosenfield'), depending on the way the raw material is obtained (different drying temperatures) and the extraction methods.

\section{MATERIAL AND METHODS}

The field experiment was carried out in the years 2014-2015 at 'The Edible Flower Collection' of the Department of Horticulture of the West Pomeranian University of Technology in Szczecin. The laboratory part of the experiment, presented in this paper was conducted in the laboratory of the Department of Horticulture of the West Pomeranian University of Technology in Szczecin. The research material consisted of one annual and three perennial ornamental plant species with edible flowers: Mimulus $\times$ hybridus L. 'Magic Yellow' and 'Magic Red', Hemerocallis $\times$ hybrida Hort., Monarda didyma L., Paeonia lactiflora Pall. 'Sarah Bernardt', 'Dr Aleksander Fleming' and 'Karl Rosenfield'.

The assumption and the course of the field experiment and the results of analyses of the fresh plant material are presented in two already published original scientific papers: Stefaniak and Grzeszczuk (2017) - M. × hybridus L., H. × hybrida Hort.,M. didyma L. and Stefaniak and Grzeszczuk (2019) - P. lactiflora Pall.

At the next stage of research, the flowers collected in full bloom were dried in 3 variants: $\sim 25^{\circ} \mathrm{C}$ - natural drying (in shade, dry room) and in the air dryer at $35^{\circ} \mathrm{C}$ and $70^{\circ} \mathrm{C}$. The time of drying the flowers at $\sim 25^{\circ} \mathrm{C}$ was, depending on the species, from 5 to 8 days, at $35^{\circ} \mathrm{C}$ from 3 to 5 days, at $70^{\circ} \mathrm{C}$ from 1 to 3 days. Then the content of vitamin $\mathrm{C}$ as L-ascorbic acid (by the method of Tillmans), total carotenoids (Lichtenthaler and Wellburn 1983), total polyphenols and antioxidant activity were determined in the dried plant material. For the determination of total polyphenols content and antioxidant activity, a sample of $1 \mathrm{~g}$ of dried and ground plant material was extracted with $80 \%$ methanol $(\mathrm{MeOH})$ to a volume of $100 \mathrm{ml}$. The mixtures were placed in an ultrasonic bath at room temperature and sonificated for 30 minutes ( $2 \times 15$ minutes), and then left for 24 hours at room temperature. The obtained extracts were filtered through Whatman No. 1 filter paper. The filtrates were centrifuged at $1500 \mathrm{rpm}$ for 10 minutes. All the extractions were carried out in three replicates. The extracts were kept in $4^{\circ} \mathrm{C}$ and used for the analyses within 24 hours. In the prepared extracts their antioxidant potential, i.e. total polyphenols, DPPH, ABTS, FRAP, was determined. The total polyphenols content was analyzed spectrophotometrically using the Folin-Ciocalteu colorimetric method described by Wojdyło et al. (2007). The method with DPPH solution (2,2-diphenyl-1-picrylhydrazil) was evaluated according to the process described by Kumaran and Karunakaran (2007) and Wojdyło et al. (2007). The method described by Wojdyło et al. (2007) was used to determine the ferric ion reducing antioxidant property (FRAP). The free-radical scavenging activity was determined by the ABTS radical decoloration procedures described by $\mathrm{Re}$ et al. (1999), Wojdyło et al. (2007) and Chew et al. (2011) with some modifications.

On the basis of the obtained results of chemical analyses, the best drying variants were selected for the studied flower species $\left(\sim 25^{\circ} \mathrm{C}\right.$ for $P$. lactiflora Pall.; $35^{\circ} \mathrm{C}-$ for all others species). The next stage was the preparation of water extracts (infusions, decoctions, 
macerates) and alcoholic extracts (with the use of 50\%, $80 \%$ and $96 \%$ ethanol and repeated extractiong method (96\% EtOH) from the selected dried flower. Infusions: $100 \mathrm{~mL}$ of boiling distilled water was added to $2 \mathrm{~g}$ of the sample and left to stand at room temperature for 10 minutes. Decoctions: $100 \mathrm{~mL}$ of hot $\left(95^{\circ} \mathrm{C}\right)$ distilled water was added to $2 \mathrm{~g}$ of the sample, and heated for 10 minutes from boiling. The mixture was left to stand at room temperature for 10 minutes. Macerates: $100 \mathrm{ml}$ distilled boiled and cooled water was added to $2 \mathrm{~g}$ of the sample and left covered for 24 hours at room temperature.

$50 \%, 80 \%$ and $96 \%$ ethanol extracts: $100 \mathrm{~mL} 50 \%, 80 \%$ or $96 \%$ ethyl alcohol was added to $0.5 \mathrm{~g}$ of the sample and left to stand at room temperature for 48 hours. Pouring method several times: $20 \mathrm{~mL}$ ethanol $96 \%$ was added to $0.5 \mathrm{~g}$ of the sample. The extracts were placed in an ultrasonic bath at room temperature and sonicated for 6 minutes and then left for 30 minutes. After this time the extract was poured into a $100 \mathrm{ml}$ flask and the plant residue was flooded again with $20 \mathrm{ml}$ of ethanol. This operation was performed 5 times until the flower petals were discoloured (ethanol with petals no longer coloured).

Water and alcohol extracts were placed in an ultrasonic bath at room temperature and subjected to ultrasonic treatment (sound frequency $40 \mathrm{kHz}$; heating option was turned off) for 30 minutes ( $2 \times 15$ minutes). The obtained extracts were filtered through Whatman No. 1 filter paper. The filtrates were centrifuged at $1500 \mathrm{rpm}$ for 10 minutes. All extractions were carried out in three repetitions. Extracts were kept at $4^{\circ} \mathrm{C}$ and used for analysis within 24 hours. The antioxidant potential of these extracts was determined, i.e.: total polyphenols, DPPH, ABTS, FRAP.

The results were statistically elaborated using the analysis of one-factor variance by applying FR-ANALWAR software based on Microsoft Excel for the system of random blocks with Tukey's half confidence intervals at the level of significance $p=0.05$.

\section{RESULTS AND DISCUSSION}

Table 1 presents the results of the experiment, which aimed at selecting the optimal drying temperature for the studied species of edible flowers. On the basis of the obtained results it was found that there were significant differences between the temperatures of drying $\left(\sim 25^{\circ} \mathrm{C}, 35^{\circ} \mathrm{C}\right.$ and $\left.70^{\circ} \mathrm{C}\right)$ in selected edible flowers with regard to the content of L-ascorbic acid, total carotenoids, total polyphenols and antioxidant activity.

Analyzing the results on the content of L-ascorbic acid, it was found that in all the studied species, except $H$. x hybrida Hort., significantly higher content of this compound was determined in flowers dried at $70^{\circ} \mathrm{C}$. This difference was attributed to the reduced drying time under forced convection (Santos and Silva 2008).

In our earlier studies, where the content of vitamin $C$ in fresh plant material was determined before drying, the amount of this component was equal to: $M . \times$ hybridus $L$. 'Magic Yellow' - average $724.7 \mathrm{mg} \cdot 100 \mathrm{~g}^{-1}$ DW; M. × hybridus L. 'Magic Red' - 559.5; M. didyma L. -177.1 ; H. $\times$ hybrida Hort. -762.1 ; P. lactiflora Pall. 'Sarah Bernardt'- 846.2, 'Dr Aleksander Fleming' - 637.8, 'Karl Rosenfield'- 794.6 and, after drying, on average for three drying temperatures respectively: M. $\times$ hybridus L. 'Magic Yellow'- $40.6 \mathrm{mg} \cdot 100 \mathrm{~g}^{-1} \mathrm{DW}$; M. × hybridus L. 'Magic Red' - 10.8; M. didyma L. - 25.5; H. × hybrida Hort. - 10.7; 
P. lactiflora Pall. 'Sarah Bernardt' - 105.2, ‘Dr. Alexander Fleming' - 66.5, ‘Karl Rosenfield' - 71.6. The losses were therefore very visible and amounted to $92.11 \%$ on average for all species. This could be explained by irreversible oxidative processes during drying or rehydratation and water lixiviation of this water-soluble vitamin (López et al. 2013) and has already been shown in many scientific studies. The highest content of vitamin $C$ in dried plant material was recorded in the case of $P$. lactiflora Pall. 'Sarah Bernardt' flowers (147.0 mg $\left.\cdot 100 \mathrm{~g}^{-1} \mathrm{DW}\right)$.

Table 1. The content of L-ascorbic acid, total carotenoids, total polyphenols and antioxidant activity in selected edible flowers at different drying temperatures

\begin{tabular}{|c|c|c|c|c|c|c|}
\hline \multirow{2}{*}{$\begin{array}{l}\text { Drying } \\
\text { temperature }\end{array}$} & \multirow{2}{*}{$\begin{array}{c}\text { L-ascorbic acid } \\
{\left[\mathrm{mg} \cdot 100 \mathrm{~g}^{-1} \mathrm{DW}\right]}\end{array}$} & \multirow{2}{*}{$\begin{array}{c}\text { Total } \\
\text { carotenoids } \\
{\left[\mu \mathrm{g} \cdot \mathrm{g}^{-1} \mathrm{DW}\right]}\end{array}$} & \multirow{2}{*}{$\begin{array}{l}\text { Total polyphenols } \\
{\left[\mathrm{mg} \mathrm{GAE} \cdot \mathrm{g}^{-1} \mathrm{DW}\right]}\end{array}$} & \multicolumn{3}{|c|}{$\begin{array}{l}\text { Antioxidant activity } \\
{\left[\mathrm{mg} \mathrm{TE} \cdot \mathrm{g}^{-1} \mathrm{DW}\right]}\end{array}$} \\
\hline & & & & DPPH & ABTS & FRAP \\
\hline \multicolumn{7}{|c|}{ Mimulus $\times$ hybridus L. 'Magic Yellow' } \\
\hline$\sim 25^{\circ} \mathrm{C}$ & $36.0 \mathrm{~b}$ & $982.3 \mathrm{~b}$ & $41.3 \mathrm{a}$ & $51.8 \mathrm{~b}$ & $164.3 \mathrm{a}$ & $18.2 \mathrm{ab}$ \\
\hline $35^{\circ} \mathrm{C}$ & $34.5 \mathrm{~b}$ & $1976.1 \mathrm{a}$ & $47.6 \mathrm{a}$ & $55.2 \mathrm{a}$ & $195.1 \mathrm{a}$ & $18.5 \mathrm{a}$ \\
\hline $70^{\circ} \mathrm{C}$ & $51.4 \mathrm{a}$ & $1980.4 \mathrm{a}$ & $41.0 \mathrm{a}$ & $50.9 \mathrm{~b}$ & $171.2 \mathrm{a}$ & $18.1 b$ \\
\hline \multicolumn{7}{|c|}{ Mimulus $\times$ hybridus L. 'Magic Red' } \\
\hline$\sim 25^{\circ} \mathrm{C}$ & $5.5 \mathrm{~b}$ & $1974.7 \mathrm{a}$ & $61.5 \mathrm{a}$ & $53.5 \mathrm{~b}$ & $270.0 \mathrm{ab}$ & $19.9 \mathrm{~b}$ \\
\hline $35^{\circ} \mathrm{C}$ & $7.0 \mathrm{~b}$ & $1692.0 \mathrm{c}$ & $65.0 \mathrm{a}$ & $58.4 \mathrm{a}$ & 319.6 a & $21.2 \mathrm{a}$ \\
\hline $70^{\circ} \mathrm{C}$ & $19.9 \mathrm{a}$ & $1790.8 \mathrm{~b}$ & $49.5 \mathrm{~b}$ & $51.6 \mathrm{~b}$ & $232.4 b$ & $19.2 \mathrm{c}$ \\
\hline \multicolumn{7}{|c|}{ Monarda didyma L. } \\
\hline$\sim 25^{\circ} \mathrm{C}$ & $16.3 \mathrm{~b}$ & 266.7 a & $66.7 \mathrm{ab}$ & $90.1 \mathrm{a}$ & 125.6 a & $32.7 \mathrm{~b}$ \\
\hline $35^{\circ} \mathrm{C}$ & $16.0 \mathrm{~b}$ & $351.5 \mathrm{a}$ & $78.2 \mathrm{a}$ & $148.4 \mathrm{a}$ & $118.5 \mathrm{a}$ & 33.3 a \\
\hline $70^{\circ} \mathrm{C}$ & $44.4 \mathrm{a}$ & $290.5 \mathrm{a}$ & $54.6 \mathrm{~b}$ & $100.9 \mathrm{a}$ & $81.9 \mathrm{a}$ & $32.5 b$ \\
\hline \multicolumn{7}{|c|}{ Hemerocallis $\times$ hybrida Hort. } \\
\hline$\sim 25^{\circ} \mathrm{C}$ & $3.8 \mathrm{c}$ & $821.4 \mathrm{a}$ & $25.2 \mathrm{~b}$ & $29.3 \mathrm{a}$ & $92.4 \mathrm{a}$ & $18.6 \mathrm{~b}$ \\
\hline $35^{\circ} \mathrm{C}$ & $19.1 \mathrm{a}$ & $912.1 \mathrm{a}$ & $27.1 \mathrm{a}$ & $30.2 \mathrm{a}$ & 66.7 a & $19.2 \mathrm{a}$ \\
\hline $70^{\circ} \mathrm{C}$ & $9.0 \mathrm{~b}$ & $808.0 \mathrm{a}$ & $21.9 c$ & $27.8 \mathrm{a}$ & $40.4 \mathrm{a}$ & $17.6 \mathrm{c}$ \\
\hline \multicolumn{7}{|c|}{ Paeonia lactiflora Pall. 'Sarah Bernardt' } \\
\hline$\sim 25^{\circ} \mathrm{C}$ & $86.1 \mathrm{~b}$ & $21.8 \mathrm{a}$ & 197.9 a & $624.0 \mathrm{a}$ & 809.4 a & $39.5 \mathrm{a}$ \\
\hline $35^{\circ} \mathrm{C}$ & $82.5 \mathrm{~b}$ & $32.3 \mathrm{a}$ & 181.9 a & 589.1 a & $751.6 \mathrm{ab}$ & 38.9 a \\
\hline $70^{\circ} \mathrm{C}$ & $147.0 \mathrm{a}$ & $20.0 \mathrm{a}$ & $172.7 \mathrm{a}$ & $541.8 \mathrm{a}$ & $666.2 \mathrm{~b}$ & $38,0 \mathrm{~b}$ \\
\hline \multicolumn{7}{|c|}{ Paeonia lactiflora Pall. 'Dr Aleksander Fleming' } \\
\hline$\sim 25^{\circ} \mathrm{C}$ & $57.6 \mathrm{~b}$ & $32.3 \mathrm{a}$ & $207.1 \mathrm{a}$ & $597.0 \mathrm{a}$ & $843.3 \mathrm{a}$ & $40.2 \mathrm{a}$ \\
\hline $35^{\circ} \mathrm{C}$ & $44.1 \mathrm{~b}$ & 35.8 a & 189.7 a & 652.9 a & $827.0 \mathrm{a}$ & $39.3 \mathrm{~b}$ \\
\hline $70^{\circ} \mathrm{C}$ & $97.7 \mathrm{a}$ & $29.4 \mathrm{a}$ & $185.2 \mathrm{a}$ & $641.1 \mathrm{a}$ & $734.5 \mathrm{a}$ & $38.9 \mathrm{~b}$ \\
\hline \multicolumn{7}{|c|}{ Paeonia lactiflora Pall. 'Karl Rosenfield' } \\
\hline$\sim 25^{\circ} \mathrm{C}$ & $42.3 c$ & $53.2 \mathrm{a}$ & 224.9 a & $717.4 \mathrm{a}$ & $850.5 \mathrm{a}$ & $40.5 \mathrm{a}$ \\
\hline $35^{\circ} \mathrm{C}$ & $78.2 \mathrm{~b}$ & $72.2 \mathrm{a}$ & $204.5 \mathrm{a}$ & $659.3 \mathrm{a}$ & 879.0 a & $39.8 \mathrm{a}$ \\
\hline $70^{\circ} \mathrm{C}$ & $94.3 \mathrm{a}$ & $82.2 \mathrm{a}$ & $215.3 \mathrm{a}$ & $711.6 \mathrm{a}$ & 841.9 a & $40.5 \mathrm{a}$ \\
\hline
\end{tabular}

Mean values in columns marked with different letters differ significantly: $a-c-P \leq 0.05$.

Studies on the content of carotenoids in fruit and vegetables show that this is a very stable group of plant colourants and resistant to high drying temperature (Regier et al. 2005; Daood et al. 2006; Nowacka et al. 2011). According to Regier et al. (2005), during carrot drying at $70^{\circ} \mathrm{C}$ or lower, the total content of carotenoids remains unchanged, lycopene is stable up to $90^{\circ} \mathrm{C}$, while $\beta$-carotene remains stable only up to $70^{\circ} \mathrm{C}$. No significant differences in carotenoid content between drying temperatures have been found in own studies in all species 
except M. x hybridusL. cultivars. The highest carotenoid accumulation was determined in M. × hybridus L. 'Magic Yellow' flowers dried at high temperature $\left(70^{\circ} \mathrm{C}\right)-1980.4 \mu \mathrm{g} \cdot \mathrm{g}^{-1} \mathrm{DW}$. The flowers of 'Magic Red' cultivar had the highest content of these compounds when dried at $\sim 25{ }^{\circ} \mathrm{C}\left(1974.7 \mu \mathrm{g} \cdot \mathrm{g}^{-1} \mathrm{DW}\right)$.

Among all the species studied, it was found that $P$. lactiflora Pall. flowers were characterized on average by the highest content of total polyphenols (197.7 $\left.\mathrm{mg} \mathrm{GAE} \cdot \mathrm{g}^{-1} \mathrm{DW}\right)$ and antioxidant activity using DPPH (637.1 $\left.\mathrm{mg} \mathrm{TE} \cdot \mathrm{g}^{-1} \mathrm{DW}\right)$, ABTS $\left(800.4 \mathrm{mg} \mathrm{TE} \cdot \mathrm{g}^{-1} \mathrm{DW}\right)$ and FRAP (39.5 mg TE $\cdot \mathrm{g}^{-1} \mathrm{DW}$ ) tests. Chen et al. (2015) report that dried flowers of $P$. lactiflora Pall. contained high content of total polyphenols $\left(222.0 \mathrm{mg} \mathrm{GAE} \cdot \mathrm{g}^{-1} \mathrm{DW}\right)$ and high activity of free radical sweeping in DPPH $\left(599.4 \mu \mathrm{mol} \mathrm{TE} \cdot \mathrm{g}^{-1} \mathrm{DW}\right)$, ABTS $\left(2078.3 \mu \mathrm{mol}\right.$ TE $\left.\cdot \mathrm{g}^{-1} \mathrm{DW}\right)$ and FRAP $\left(836.7 \mu \mathrm{mol}\right.$ TE $\left.\cdot \mathrm{g}^{-1} \mathrm{DW}\right)$ tests.

However, the scientific literature lacks information on the content of biologically active compounds in edible flowers subjected to different drying temperatures. In an earlier published study (Stefaniak and Grzeszczuk 2019) the total polyphenol content (calculated on the dry matter of $33.1,58.5 \mathrm{mg} \mathrm{GAE} \cdot \mathrm{g}^{-1} \mathrm{DW}$ ) and the content of the antioxidant assay performed DPPH (33.5, $\left.43.8 \mathrm{mg} \mathrm{TE} \cdot \mathrm{g}^{-1} \mathrm{DW}\right)$, ABTS (112.1, $\left.149.7 \mathrm{mg} \mathrm{TE} \cdot \mathrm{g}^{-1} \mathrm{DW}\right)$, FRAP (38.8, $84.9 \mathrm{mg} \mathrm{TE} \cdot \mathrm{g}^{-1} \mathrm{DW}$ ) was determined in fresh flowers $M$. $\times$ hybridus L. 'Magic Yellow' and 'Magic Red'. After drying flowers of the same species and cultivars and averaging the results from three drying temperatures, a higher content of total polyphenols $\left(45.3,58.7 \mathrm{mg} \mathrm{GAE} \cdot \mathrm{g}^{-1} \mathrm{DW}\right)$ and antioxidant activity was observed in the DPPH $\left(52.6,54.5 \mathrm{mg} \mathrm{TE} \cdot \mathrm{g}^{-1} \mathrm{DW}\right)$ and ABTS (176.8, $\left.274.0 \mathrm{mg} \mathrm{TE} \cdot \mathrm{g}^{-1} \mathrm{DW}\right)$ tests, whereas in the FRAP test the values were lower (18.3, $\left.20.1 \mathrm{mg} \mathrm{TE} \cdot \mathrm{g}^{-1} \mathrm{DW}\right)$. A similar relationship was observed in M. didyma L. and $P$. lactiflora Pall. 'Dr. Aleksander Fleming', where the flowers after drying contained more polyphenols in total (on average for three drying temperatures by $16.5 \%$ and $10.4 \%$ respectively), DPPH (by $186.6 \%$ and $84.3 \%$ ) and ABTS (by $53.0 \%$ and $46.3 \%$ ). The flowers of $H$. $\times$ hybrida Hort. subjected to three drying temperatures were characterized on average by 1.8 times higher content of total polyphenols (on average by $184.0 \%$ ), whereas in the flowers of $P$. lactiflora Pall. 'Sarah Bernardt' higher antioxidant activity in the DPPH and ABTS tests (on average by $1.8 \%$ and $1.5 \%$ ) was demonstrated. A decrease in antioxidant activity in FRAP was shown in all tested species and cultivars in flowers subjected to three drying temperatures. Drying of $P$. lactiflora Pall flowers 'Karl Rosenfield' decreases the total polyphenol content and also the antioxidant activity in comparison to the content of these compounds in fresh flowers (Stefaniak and Grzeszczuk 2019).

On the basis of the obtained results of chemical analyses, the best drying variants of the studied flower species were identified. For flowers of $M . \times$ hybridus L. (both cultivars), M. didyma L. and $H . \times$ hybrida Hort $35^{\circ} \mathrm{C}$ was assumed as the most favourable drying temperature. Flowers of $M . \times$ hybridus $\mathrm{L}$. dried at this temperature were characterized by a high content of total polyphenols, DPPH, ABTS and FRAP, flowers of M. didyma L. contained high content of carotenoids, total polyphenols, DPPH and FRAP, and flowers of $H$. $\times$ hybrida Hort. additionally were characterized by high content of L-ascorbic acid. In the case of three studied cultivars of $P$. lactiflora Pall. the most favourable drying temperature was $\sim 25^{\circ} \mathrm{C}$. Flowers of $P$. lactiflora Pall. 'Sarah Bernardt' dried at this temperature were characterized by higher content of total polyphenols, DPPH, ABTS 
and FRAP, 'Dr Aleksander Fleming' flowers were characterized by higher content of total polyphenols, ABTS and FRAP, while 'Karl Rosenfield' flowers - total polyphenols, DPPH and FRAP.

Extraction methods carried out on the selected material have shown significant differences in total polyphenol content and antioxidant activity based on the ABTS, FRAP and DPPH methods used, as illustrated in Table 2.

Table 2. The content of total polyphenols and antioxidant activity according to the different methods used for the extraction of dried flowers of Mimulus $\times$ hybridus L., Monarda didyma L. and Paeonia lactiflora Pall.

\begin{tabular}{|c|c|c|c|c|}
\hline \multirow{2}{*}{ Extraction method } & \multirow{2}{*}{ 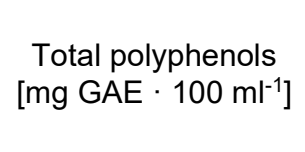 } & \multicolumn{3}{|c|}{$\begin{array}{l}\text { Antioxidant activity } \\
{\left[\mathrm{mg} \mathrm{TE} \cdot 100 \mathrm{ml}^{-1}\right]}\end{array}$} \\
\hline & & DPPH & ABTS & FRAP \\
\hline \multicolumn{5}{|c|}{ Mimulus $\times$ hybridus L. 'Magic Yellow' } \\
\hline Infusion & $46.7 \mathrm{~b}$ & $65.4 \mathrm{~b}$ & $144.7 \mathrm{~b}$ & $16.5 \mathrm{~b}$ \\
\hline Decoction & $93.8 \mathrm{a}$ & $88.5 \mathrm{a}$ & $261.6 \mathrm{a}$ & $20.5 \mathrm{a}$ \\
\hline Maceration & $39.2 \mathrm{~b}$ & $28.4 \mathrm{c}$ & $105.2 \mathrm{c}$ & $16.4 \mathrm{~b}$ \\
\hline $50 \% \mathrm{EtOH}$ & $26.5 \mathrm{c}$ & $22.0 \mathrm{~d}$ & $46.4 \mathrm{~d}$ & $15.5 \mathrm{c}$ \\
\hline $80 \% \mathrm{EtOH}$ & $24.3 \mathrm{c}$ & $21.6 \mathrm{~d}$ & $52.0 \mathrm{~d}$ & $15.7 \mathrm{c}$ \\
\hline $96 \% \mathrm{EtOH}$ & $17.1 \mathrm{~cd}$ & $15.3 \mathrm{e}$ & $22.6 \mathrm{e}$ & $15.3 \mathrm{c}$ \\
\hline Repeated flooding method $(96 \% \mathrm{EtOH})$ & $13.4 \mathrm{~d}$ & $13.3 \mathrm{e}$ & $21.2 \mathrm{e}$ & $15.6 \mathrm{c}$ \\
\hline \multicolumn{5}{|c|}{ Mimulus $\times$ hybridus L. 'Magic Red' } \\
\hline Infusion & $57.1 \mathrm{~b}$ & $77.1 \mathrm{~b}$ & $138.4 \mathrm{c}$ & $18.3 \mathrm{~b}$ \\
\hline Decoction & $113.5 \mathrm{a}$ & $85.6 a$ & $384.9 \mathrm{a}$ & $23.9 \mathrm{a}$ \\
\hline Maceration & $63.1 \mathrm{~b}$ & $50.4 \mathrm{c}$ & $223.4 \mathrm{~b}$ & $19.2 \mathrm{~b}$ \\
\hline $50 \% \mathrm{EtOH}$ & $36.1 \mathrm{c}$ & $22.3 \mathrm{~d}$ & $80.3 \mathrm{~d}$ & $16.4 \mathrm{c}$ \\
\hline $80 \% \mathrm{EtOH}$ & $28.2 \mathrm{~d}$ & $22.0 \mathrm{~d}$ & $65.4 \mathrm{de}$ & $15.8 \mathrm{~cd}$ \\
\hline $96 \% \mathrm{EtOH}$ & $16.0 \mathrm{e}$ & $14.3 \mathrm{e}$ & $31.9 \mathrm{e}$ & $14.7 \mathrm{~cd}$ \\
\hline Repeated flooding method (96\% EtOH) & $16.5 \mathrm{e}$ & $13.2 \mathrm{e}$ & $28.0 \mathrm{e}$ & $14.2 \mathrm{~d}$ \\
\hline \multicolumn{5}{|c|}{ Monarda didyma L. } \\
\hline Infusion & $65.2 \mathrm{~b}$ & $118.3 \mathrm{~b}$ & $109.2 \mathrm{bc}$ & $17.8 \mathrm{~b}$ \\
\hline Decoction & $117.9 \mathrm{a}$ & $257.4 \mathrm{a}$ & $383.3 \mathrm{a}$ & $22.7 \mathrm{a}$ \\
\hline Maceration & $67.1 \mathrm{~b}$ & $118.3 \mathrm{~b}$ & $202.3 \mathrm{~b}$ & $17.8 \mathrm{~b}$ \\
\hline $50 \% \mathrm{EtOH}$ & $21.5 \mathrm{c}$ & $18.0 \mathrm{c}$ & $7.1 \mathrm{c}$ & $15.4 \mathrm{~b}$ \\
\hline $80 \% \mathrm{EtOH}$ & $18.1 \mathrm{c}$ & $18.5 \mathrm{c}$ & $8.9 \mathrm{c}$ & $15.3 \mathrm{~b}$ \\
\hline $96 \% \mathrm{EtOH}$ & $1.7 \mathrm{~d}$ & $3.0 \mathrm{c}$ & $3.8 \mathrm{c}$ & $3.4 \mathrm{c}$ \\
\hline Repeated flooding method (96\% EtOH) & $0.3 \mathrm{~d}$ & $1.7 \mathrm{c}$ & $1.7 \mathrm{c}$ & $1.2 \mathrm{c}$ \\
\hline \multicolumn{5}{|c|}{ Hemerocallis $\times$ hybrida Hort. } \\
\hline Infusion & $49.0 \mathrm{~b}$ & $62.4 \mathrm{a}$ & $99.8 \mathrm{~b}$ & $16.1 \mathrm{a}$ \\
\hline Decoction & $57.8 \mathrm{a}$ & $63.1 \mathrm{a}$ & $100.4 \mathrm{~b}$ & $16.3 \mathrm{a}$ \\
\hline Maceration & $55.9 \mathrm{a}$ & $38.9 \mathrm{~b}$ & $143.1 \mathrm{a}$ & $16.3 \mathrm{a}$ \\
\hline $50 \% \mathrm{EtOH}$ & $15.2 \mathrm{c}$ & $14.0 \mathrm{c}$ & $24.1 \mathrm{c}$ & $14.2 \mathrm{~b}$ \\
\hline $80 \% \mathrm{EtOH}$ & $14.1 \mathrm{~cd}$ & $12.4 \mathrm{~cd}$ & $23.0 \mathrm{c}$ & $13.2 \mathrm{~b}$ \\
\hline $96 \% \mathrm{EtOH}$ & $8.7 \mathrm{e}$ & $5.7 \mathrm{~d}$ & $10.5 \mathrm{c}$ & $8.2 \mathrm{c}$ \\
\hline Repeated flooding method (96\% EtOH) & $10.4 \mathrm{de}$ & $5.7 \mathrm{~d}$ & $10.6 \mathrm{c}$ & $6.7 \mathrm{~d}$ \\
\hline \multicolumn{5}{|c|}{ Paeonia lactiflora Pall. 'Sarah Bernardt' } \\
\hline Infusion & $117.9 \mathrm{~b}$ & $527.0 \mathrm{~b}$ & $669.2 \mathrm{bc}$ & $110.5 \mathrm{ab}$ \\
\hline Decoction & $397.1 \mathrm{a}$ & $1294.4 \mathrm{a}$ & $1553.1 \mathrm{a}$ & $122.1 \mathrm{a}$ \\
\hline Maceration & $134.4 \mathrm{~b}$ & $619.7 \mathrm{~b}$ & $761.5 \mathrm{~b}$ & $112.4 \mathrm{ab}$ \\
\hline $50 \% \mathrm{EtOH}$ & $88.1 \mathrm{~b}$ & $367.2 \mathrm{bc}$ & $571.6 \mathrm{bc}$ & $93.9 \mathrm{c}$ \\
\hline $80 \% \mathrm{EtOH}$ & $96.3 \mathrm{~b}$ & $347.7 \mathrm{bc}$ & $342.2 \mathrm{bc}$ & $100.0 \mathrm{bc}$ \\
\hline $96 \% \mathrm{EtOH}$ & $44.7 \mathrm{c}$ & $262.2 \mathrm{bc}$ & $172.1 \mathrm{bc}$ & $53.8 \mathrm{~d}$ \\
\hline Repeated flooding method (96\% EtOH) & $18.6 \mathrm{c}$ & $69.6 \mathrm{c}$ & $45.5 \mathrm{c}$ & $28.4 \mathrm{~d}$ \\
\hline
\end{tabular}


Table 2. The content of total polyphenols and antioxidant activity according to the different methods used for the extraction of dried flowers of Mimulus $\times$ hybridus L., Monarda didyma L. and Paeonia lactiflora Pall. (cont.)

\begin{tabular}{|c|c|c|c|c|}
\hline \multirow[t]{2}{*}{ Extraction method } & \multirow{2}{*}{$\begin{array}{l}\text { Total polyphenols } \\
{\left[\mathrm{mg} \mathrm{GAE} \cdot 100 \mathrm{ml}^{-1} \text { ] }\right.}\end{array}$} & \multicolumn{3}{|c|}{$\begin{array}{l}\text { Antioxidant activity } \\
{\left[\mathrm{mg} \mathrm{TE} \cdot 100 \mathrm{ml}^{-1} \text { ] }\right.}\end{array}$} \\
\hline & & DPPH & ABTS & FRAP \\
\hline \multicolumn{5}{|c|}{ Paeonia lactiflora Pall. 'Dr Aleksander Fleming' } \\
\hline Infusion & $127.6 \mathrm{c}$ & $588.0 \mathrm{~b}$ & $557.7 \mathrm{~b}$ & $111.8 \mathrm{ab}$ \\
\hline Decoction & $351.0 \mathrm{a}$ & $1224.8 \mathrm{a}$ & $1451.7 \mathrm{a}$ & $120.4 \mathrm{a}$ \\
\hline Maceration & $154.8 \mathrm{~b}$ & $662.4 \mathrm{~b}$ & $838.6 \mathrm{~b}$ & $113.5 \mathrm{ab}$ \\
\hline $50 \% \mathrm{EtOH}$ & $86.0 \mathrm{~d}$ & $406.1 \mathrm{bc}$ & $125.2 \mathrm{~cd}$ & $90.7 \mathrm{bc}$ \\
\hline $80 \% \mathrm{EtOH}$ & $92.7 \mathrm{~d}$ & $400.2 \mathrm{bc}$ & $458.8 \mathrm{bc}$ & $67.6 \mathrm{~cd}$ \\
\hline $96 \% \mathrm{EtOH}$ & $39.7 \mathrm{e}$ & $130.5 \mathrm{~cd}$ & $100.9 \mathrm{~cd}$ & $49.3 \mathrm{de}$ \\
\hline Repeated flooding method (96\% EtOH) & $18.0 \mathrm{e}$ & $89.1 \mathrm{~d}$ & $43.5 \mathrm{~d}$ & $32.4 \mathrm{e}$ \\
\hline \multicolumn{5}{|c|}{ Paeonia lactiflora Pall. 'Karl Rosenfield' } \\
\hline Infusion & $99.5 \mathrm{~b}$ & $468.5 \mathrm{~b}$ & $435.1 \mathrm{bc}$ & $110.0 \mathrm{ab}$ \\
\hline Decoction & $353.6 \mathrm{a}$ & $1166.4 \mathrm{a}$ & $1216.3 \mathrm{a}$ & $120.9 \mathrm{a}$ \\
\hline Maceration & $151.4 \mathrm{~b}$ & $589.2 \mathrm{~b}$ & $751.6 \mathrm{~b}$ & $112.4 \mathrm{ab}$ \\
\hline $50 \% \mathrm{EtOH}$ & $97.9 \mathrm{~b}$ & $342.8 \mathrm{~b}$ & $141.2 \mathrm{c}$ & $93.1 \mathrm{~b}$ \\
\hline $80 \% \mathrm{EtOH}$ & $103.0 \mathrm{~b}$ & $457.5 \mathrm{~b}$ & $399.5 \mathrm{bc}$ & $103.1 \mathrm{ab}$ \\
\hline $96 \% \mathrm{EtOH}$ & $22.8 \mathrm{~b}$ & $89.1 \mathrm{~b}$ & $63.3 \mathrm{c}$ & $30.3 \mathrm{c}$ \\
\hline Repeated flooding method (96\% EtOH) & $6.0 \mathrm{~b}$ & $42.7 \mathrm{~b}$ & $5.9 \mathrm{c}$ & $12.2 \mathrm{c}$ \\
\hline
\end{tabular}

Mean values in columns marked with different letters differ significantly: $a-e-P \leq 0.05$.

It was observed in the conducted experiments that for all investigated species and cultivars the decoction method was the most advantageous because it proved the highest content of antioxidant compounds (Table 2). Moreover, the highest contents of the studied compounds were found in the methods of flower extraction of three cultivars of $P$. lactiflora Pall. P. lactiflora Pall. 'Sarah Bernardt' flower decoctions indicate the highest antioxidant activity: total polyphenols - $397.1 \mathrm{mg} \mathrm{GAE} \cdot 100 \mathrm{ml}^{-1}$; DPPH - $1294.4 \mathrm{mg} \mathrm{TE} \cdot 100 \mathrm{ml}^{-1}$; ABTS - $1553.1 \mathrm{mg} \mathrm{TE} \cdot 100 \mathrm{ml}^{-1}$; FRAP - $122.1 \mathrm{mg} \mathrm{TE} \cdot 100 \mathrm{ml}^{-1}$. Testing antioxidant activity with FRAP test in P. lactiflora Pall. 'Sarah Bernardt' and 'Dr. Alexander Fleming' flowers no statistically significant differences were found between infusion, decoction and macerate, and in the case of 'Karl Rosenfield' flowers, no statistically significant differences were found between water extracts and $80 \%$ ethanol extract. Moreover, infusion, macerate and alcohol extracts from 'Karl Rosenfield' flowers did not differ significantly from each other in the case of total polyphenols and antioxidant compounds tested by DPPH test.

In M. didyma L. flower decoctions high content of total polyphenols (117.9 mg GAE $100 \mathrm{ml}^{-1}$ ) and high antioxidant activity by DPPH method $\left(257.4 \mathrm{mg} \mathrm{TE} \cdot 100 \mathrm{ml}^{-1}\right.$ ) were observed. Whereas, flower decoctions from $M . \times$ hybridus L. 'Magic Red' showed high antioxidant activity in ABTS (384.9 mg TE $\left.\cdot 100 \mathrm{ml}^{-1}\right)$ i FRAP $\left(23.9 \mathrm{mg} \mathrm{TE} \cdot 100 \mathrm{ml}^{-1}\right)$ tests.

In this study it was noted that $H . \times$ hybrida Hort. flowers showed significantly higher antioxidant activity in the ABTS test when extracted by maceration rather than by decoction (29\% on average).At the same time, for the investigated species, decoctions and infusions indicated higher antioxidant activity in the DPPH test than macerates (on average $38 \%$ ), there were no significant differences between infusions, decoctions and macerates in the FRAP test. 
Moreover, in dried $H . \times$ hybrida Hort. flowers, decoctions and macerates were the most effective methods to achieve high polyphenol content. A study by Ngoitaku et al. (2016) on the duration of tea brewing from edible flowers of 8 other ornamental plant species showed that Tagetes erecta tea brewed at $100^{\circ} \mathrm{C}$ for 3 minutes contained a high level of total phenol content (35.5 mg GAE $\cdot \mathrm{g}^{-1} \mathrm{DW}$ ). Whereas, $T$. erecta tea drinks brewed at $95^{\circ} \mathrm{C}$ for 5 minutes showed the highest total reducing capacity (FRAP test $-36.1 \mu \mathrm{mol} \mathrm{FeSO} 4 \cdot \mathrm{g}^{-1} \mathrm{DW}$ ).

Based on the results obtained in the research of selected edible flower species, it was found that water extracts indicate higher antioxidant activity than alcohol extracts. The decoction was also the most advantageous extraction method for the tested species of edible flowers. Similar results were obtained by Grzeszczuk et al. (2014). Based on dried plant material (vinca herbs and leaves) the authors had prepared three types of water extracts: infusions, decoctions and macerates. Decoction was found to be the most effective method of water extraction as it resulted in the highest content of biologically active compounds (L-ascorbic acid, total polyphenols) and antioxidant activity.

It should also be emphasized that regardless of the species, extracts with $50 \%$ and $80 \%$ ethanol were characterized by the higher content of total polyphenols and antioxidant compounds than extracts with $96 \%$ ethanol or using multiple flooding with the same high percentage alcohol.

\section{CONCLUSIONS}

1. Dried edible flowers demonstrated high content of biologically active compounds, especially total polyphenols, total carotenoids and antioxidant activity. For the flowers of $M . \times$ hybridus L., M. didyma L. and $H . \times$ hybrida Hort. the most favourable drying temperature was $35^{\circ} \mathrm{C}$, while for the flowers of $P$. lactiflora Pall. $\sim 25^{\circ} \mathrm{C}$.

2. Water extracts indicate higher antioxidant activity in comparison with the alcohol extracts.

3. The decoction was the most efficient method of extraction of the studied species of edible flowers.

4. Water-alcoholic extracts $(50 \%$ and $80 \%$ ethanol) indicated better antioxidant properties than alcoholic ones (96\% and repeated flooding with $96 \%$ ethanol).

5. Among the extracts of the dried edible flowers evaluated in the experiment, the highest antioxidant activity was observed in water and water-alcohol extracts prepared on the basis of peony flowers.

\section{ACKNOWLEDGMENT}

Research was financed by West Pomeranian University of Technology in Szczecin as a part of statutory activity.

\section{REFERENCES}

Adamczak A., Forycka A., Buchwald W. 2015. Skład herbatek owocowych dostępnych na polskim rynku artykułów spożywczych [The composition of fruit teas available on the polish market of foodstuffs]. Post. Fitoter. 4, 216-222. [in Polish] 
Araújo C.R.R., Silva T.M., Lopes M., Villela P., Alcântara A.F.C., Dessimoni-Pinto N.A.V. 2013. Total antioxidant capacity, total phenolic content and mineral elements in the fruit peel of Myrciaria cauliflora. Brazil. J. Food Tech. 16(4), 30-309.

Benvenuti S., Bortolotti E., Maggini R. 2016. Antioxidant power, anthocyanin content and organoleptic performance of edible flowers. Scientia Hort. 199,170-177.

Chen G.L., Chen S.G, Xiao Y., Fu N.L. 2018. Antioxidant capacities and total phenolic contents of 30 flowers. Ind. Crop. Prod. 111, 430-445.

Chen G-L., Chen S-G., Xie Y-Q., Chen F., Zhao Y-Y., Luo C-X., Gao Y-Q. 2015. Total phenolic, flavonoid and antioxidant activity of 23 edible flowers subjected to in vitro digestion. J. Funct. Foods 17, 243-259.

Chew K.K., Khoo M.Z., Ng S.Y., Thoo Y.Y., Wan Aida W.M., Ho C.W. 2011. Effect of ethanol concentration, extraction time and extraction temperature on the recovery of phenolic compounds and antioxidant capacity of Orthosiphon stamineus extracts. Int. Food Res. J. 18, 1427-1435.

Cybul M., Nowak R. 2008. Przegląd metod stosowanych w analizie właściwości antyoksydacyjnych wyciągów roślinnych [Review of the methods applied to measuring of antioxidant activity of plant extracts]. Herba Pol. 54(1), 68-78. [in Polish]

Daood H.G., Kapitány J., Biacs P., Albrecht K. 2006. Drying temperature, endogenousantioxidants and capsaicinoids affect carotenoid stability in paprika (red pepper spice). J. Sci. Food Agric. 86, 2450-2457.

Friedman H., Agami O., Vinokur Y., Droby S., Cohen L., Refaeli G., Resnick N., Umiel N. 2010. Characterization of yield, sensitivity to Botrytis cinerea and antioxidant content of several rose species suitable for edible flowers. Sci. Hort. 123, 395-401.

González-Barrio R., Periago M.J., Luna-Recio C., Javier G-A.F., Navarro-González I. 2018. Chemical composition of the edible flowers, pansy (Viola wittrockiana) and snapdragon (Antirrhinum majus) as new sources of bioactive compounds. Food Chem. 252, 373-380.

Grzeszczuk M., Stefaniak A., Pachlowska A. 2016. Biological value of various edible flower species. Acta Sci. Pol. 15(2), 109-119.

Grzeszczuk M., Wilas J., Wałejko A., Sitarz E. 2014.Content of biologically active compounds in water extracts of periwinkle (Catharanthus roseus (I.) G. Don). J. Internat. Sci. Public., Agric. Food. 2, 117-124.

Hussain N., Ishak I., Mohd Harith N., Leong Pau Kuan G. 2019. Comparison of bioactive compounds and sensory evaluation on edible flowers tea infusion. Ital. J. Food. Sci. 31, 264-273.

Kaisoon O., Konczak I., Siriamornpun S. 2012. Potential health enhancing properties of edible flowers from Thailand. Food Res. Inter. 46, 56-571.

Kelly K.M., Behe B.K., Biernbaum J.A., Poff K.L. 2001. Consumer preference for edible flower color, container size, and price. Hort. Sci.36, 801-804.

Koike A., Barreira J.C.M., Barros L., Santos-Buelga C., Villavicencio A.L.C.H., Ferreira I.C.F.R. 2015. Edible flowers of Viola tricolor L. as a new functional food: antioxidant activity, individual phenolics and effects of gamma and electron-beam irradiation. Food Chem. 179, 6-14.

Kumaran A., Karunakaran R.J. 2007. In vitro antioxidant activities of methanol extracts of five Phyllanthus species from India. LWT - Food Sci. Technol. 40, 344-352.

Lara-Cortés E., Osorio-Díaz P., Jiménez-Aparicio A., Bautista-Baños S. 2013. Contenido nutricional, propiedades funcionales y conservación de flores comestibles. Archivos Latinoamericanos de Nutrición 63(3), 197-208.

Leonti M. 2012. The co-evolutionary perspective of the food-medicine continuum and wild gathered and cultivated vegetables. Genet. Resour. Crop. Evol. 59(7), 1295-1302.

Lichtenthaler H.K., Wellburn A.R. 1983. Determination of total carotenoids and chlorophylls a and b of leaf extracts in different solvents. Biochem. Soc. T. 603, 591-592.

Loizzo M.R., Pugliese A., Bonesi M., Tenuta M.C., Menichini F., Xiao J., Tundis R. 2016. Edible flowers: A rich source of phytochemicals with antioxidant and hypoglycaemic activity. J. Agr. Food Chem. 64, 2467-2474. 
López J., Vega-Gálvez A., Torres M.J., Lemus-Mondaca R.,Quispe-Fuentes I., Di Scala K. 2013. Effect of dehydration temperature on physico-chemical properties and antioxidant capacity of goldenberry (Physalis peruviana L.). Chile J. Agric. Res. 73(3), 293-300.

Łuczaj Ł., Pieroni A., Tardío J., Pardo-de-Santayana M., Sõukand R., Svanberg I., Kalle R. 2012. Wild food plant use in 21st century Europe: the disappearance of old traditions and the search for new cuisines involving wild edibles. Acta. Soc. Bot. Pol. 81(4), 359-370.

Matyjaszczyk E., Śmiechowska M. 2019. Edible flowers. Benefits and risks pertaining to their consumption. Trends Food Sci. Tech. 91, 670-674.

Mlcek J., Rop O. 2011. Fresh edible flowers of ornamental plants - a new source of nutraceutical foods. Trends Food Sci. Tech. 22, 561-569.

Navarro-González I., González-Barrio R., García-Valverde V., Bautista-Ortín A.B., Periago M.J. 2015. Nutritional composition and antioxidant capacity in edible flowers: Characterisation of phenolic compounds by HPLC-DAD-ESI/MSn. Int. J. Mol. Sci. 16, 805-822.

Ngoitaku C., Kwannate P., Riangwong K. 2016. Total phenolic content and antioxidant activities of edible flower tea products from Thailand. Int. Food Res. J. 23(5), 2286-2290.

Nowacka M., Witrowa-Rajchert D., Strachota W., Sobczak E. 2011. Zmiany zawartości witaminy C i karotenoidów $w$ przechowywanych suszach marchwi i ziemniaka [Changes in the content of vitamin $C$ and carotenoids during dried carrot and potato storage]. Acta Agroph. 17(1), 165-175. [in Polish]

Nurul S. R., Asmah R. 2012. Evaluation of antioxidant properties in fresh and pickled papaya. Inter. Food Res. J. 19, 1117-1124.

Petrova I., Petkova N., Ivanov I. 2016. Five edible flowers - valuable source of antioxidants in human nutrition. Int. J. Pharm. Phytopharm. Res. 8(4), 604-610.

Pires T.C.S.P., Dias M.I., Barros L., Ferreira I.C.F.R. 2017. Nutritional and chemical characterization of edible petals and corresponding infusions: Valorization as new food ingredients. Food Chem. 220, 337-343.

Re R., Pellegrini N., Proteggente A., Pannala A., Yang M., Rice-Evans C. 1999. Antioxidant activity applying an improved ABTS radical cation decolorization assay. Free Radical Biol. Med. 26(9/10),1231-1237.

Regier M., Mayer-Miebach E., Behsnilian D., Neff E., Schuchmann H.P. 2005. Influences of drying and storage of lycopene-rich carrots on the carotenoid content. Drying Technol. 23, 989-998.

Rezende F., Sande D., Coelho A.C., Oliveira G., Boaventura M.A., Takahashi J.A. 2019. Edible Flowers as Innovative Ingredients for Future Food Development: Anti-alzheimer, Antimicrobial, and Antioxidant Potential. Chem. Eng. Trans. 75, 337-342.

Rop O., Mlcek J., Jurikova T., Neugebauerova J., Vabkova J. 2012. Edible flowers - a new promising source of mineral elements in human nutrition. Molecules 17, 6672-6683.

Santos P.H.S., Silva M.A. 2008. Retention of vitamin C in drying processes of fruits and vegetables. A review: Ann. Inter. J., Drying Technol. 26(12), 1421-1437.

Stefaniak A., Grzeszczuk M. 2015. Charakterystyka wybranych gatunków roślin ozdobnych o kwiatach jadalnych [Characterisation of some ornamental plant species with edible flowers]. Ann. UMCS, Hort. 25(4), 63-73. [in Polish]

Stefaniak A., Grzeszczuk M. 2017. Ocena wartości biologicznej kwiatów wybranych odmian piwonii chińskiej (Paeonia lactiflora Pall.) [Estimation of biological value of flowers of selected Chinese peony (Paeonia lactiflora Pall.) cultivars]. Ann. UMCS, Hort. 27(4), 33-42. [in Polish]

Stefaniak A., Grzeszczuk M. 2019. Nutritional and biological value of five edible flower species. Not. Bot. Hort. Agrobot. 47(1),128-134.

Śmiechowska M. 2018. Czynniki wpływające na atrakcyjność kwiatów jadalnych [Factors that influence attractiveness of edible flowers]. Eng. Sci. Technol. 1(28), 42-49. [in Polish]

Toda S. 2011. Polyphenol content and antioxidant effects in herb teas. Chinese Med. Sci. Res. 2, 29-31.

Wojdyło A., Oszmiański J., Czemerys R. 2007. Antioxidant activity and phenolic compounds in 32 selected herbs. Food Chem. 105, 940-949. 
Xiong L., Yang J., Jiang Y., Lu B., Hu Y., Zhou F., Mao S., Shen C. 2014. Phenolic compounds and antioxidant capacities of 10 common edible flowers from China. J. Food Sci. 79(4), 517-525.

Zheng J., Meenua M., Xu B. 2019. A systematic investigation on free phenolic acids and flavonoidsprofiles of commonly consumed edible flowers in China. J. Pharm. Biomed. Anal. 172, 268-277.

\title{
WPŁYW TEMPERATURY SUSZENIA ORAZ METODY SPORZADZANIA WYCIĄGÓW NA AKTYWNOŚĆ ANTYOKSYDACYJNA KWIATÓW JADALNYCH WYBRANYCH GATUNKÓW ROŚLIN OZDOBNYCH
}

\begin{abstract}
Streszczenie. Kwiaty jadalne są popularnym składnikiem potraw wielu kuchni regionalnych, zwłaszcza azjatyckiej i bliskowschodniej. Suszenie to jedna z najpopularniejszych metod konserwacji kwiatów. Z kolei powszechną metodą spożywania wysuszonych kwiatów jadalnych jest przyrządzanie z ich wykorzystaniem różnego rodzaju napojów - zarówno alkoholowych, jak i bezalkoholowych. W pracy przedstawiono wyniki badań laboratoryjnych dotyczące zawartości związków biologicznie czynnych w kwiatach suszonych, w trzech wariantach temperaturowych $\left(\sim 25^{\circ} \mathrm{C}, 35^{\circ} \mathrm{C}\right.$ i $\left.70^{\circ} \mathrm{C}\right)$, które posłużyły do wyboru materiału stanowiącego podstawę otrzymywania różnego rodzaju wyciągów wodnych (naparów, odwarów, maceratów) i alkoholowych (z użyciem etanolu w ilości $50 \%, 80 \%$ i $96 \%$ oraz metodą kilkukrotnego zalewania $96 \% \mathrm{EtOH}$ ), a następnie oceniono ich aktywność antyoksydacyjną. Materiałem badawczym były gatunki roślin ozdobnych, których kwiaty charakteryzują się wysoką wartością biologiczną: Mimulus $\times$ hybridus L. ('Magic Yellow' and 'Magic Red'), Hemerocallis $\times$ hybrida Hort., Monarda didyma L., Paeonia lactiflora Pall. ('Sarah Bernardt', 'Dr Aleksander Fleming' and 'Karl Rosenfield'). Badania przeprowadzono w latach 2014-2015 w Katedrze Ogrodnictwa na Zachodniopomorskim Uniwersytecie Technologicznym w Szczecinie. Na podstawie uzyskanych wyników analiz chemicznych wytypowano najlepsze warianty suszenia badanych gatunków kwiatów. Dla kwiatów M. × hybridus L., M. didyma L. i $H$. × hybrida Hort. najkorzystniejszą temperaturą suszenia było $35^{\circ} \mathrm{C}$; wysuszone kwiaty charakteryzowały się największą zawartością związków biologicznie czynnych i największą aktywnością antyoksydacyjną. W przypadku trzech odmian $P$. lactiflora Pall. najkorzystniejszą temperaturą suszenia było $\sim 25^{\circ} \mathrm{C}$. Wśród wyciągów wodnych i alkoholowych badanych gatunków kwiatów jadalnych odwar charakteryzował się wysoką zawartością związków antyoksydacyjnych. Największą aktywnością antyoksydacyjną wyróżniały się wyciągi sporządzone na bazie kwiatów piwonii.
\end{abstract}

Słowa kluczowe: Mimulus, Monarda, Hemerocallis, Paeonia, witamina C, karotenoidy, polifenole, DPPH, ABTS, FRAP. 